\title{
Mainstream and evolutionary views of technology, economic growth and catching up
}

\section{Juan Ricardo Perilla Jimenez ${ }^{1}$}

Published online: 4 February 2019

(C) The Author(s) 2019

\begin{abstract}
A critical appraisal of the literature is provided with a focus on the theoretical differences underlining the mainstream and evolutionary economics of the role of technology on the ability of backward countries to catch up. The policy implications derived from these contesting approaches are illustrated in the context of the National Innovation Systems framework and the conventional debate over the advantage of backwardness. We stress that the evolutionary theory stands for a broad view of innovation and the systems literature for active public action toward the leadership, sponsorship and coordination of (local) innovation, which are positions that contrast with the theoretical views of neoclassical economics.
\end{abstract}

Keywords Economic development and growth · Technology change $\cdot$ Innovation

JEL Classification $011 \cdot 030 \cdot 043 \cdot 057$

\section{Introduction}

The purpose of this paper is to revisit the debate on the relationship between technology and international differences in economic growth. Our focus is on the distinction between the economic contributions of the adoption of foreign technology and local innovation from the perspective of two contrasting theoretical developments, namely

Juan Ricardo Perilla Jimenez

j.perillajimenez@maastrichtuniversity.nl

1 School of Business and Economics, Maastricht University, Room F2.17, Tongersestraat 53, 6211 LM Maastricht, The Netherlands 
the mainstream neoclassical and evolutionary economics. ${ }^{1,2}$ In this context, we discuss the controversy that has arisen from the critiques of evolutionary economists to the neoclassical approach in regard to the study of technology, technology diffusion and economic growth in backward countries.

The importance of technology in explaining income and income growth differences across countries is apparent. A vast amount of specialized literature agrees that the productivity of workers is closely related to a country's available technology. On some accounts, productivity, or technology, differences are held to explain up to between $60 \%$ and $90 \%$ of the growth differences and more than $90 \%$ of the difference in levels of income between poor and rich countries. ${ }^{3}$

Yet, there is less agreement among growth economists when it comes to accounting for the sources of technology progress. Among mainstream economists there is a widespread - though not unanimous - tendency to associate technology in a narrow way basically with "high-tech" developments; and foreign technology is held to account for the "lion's share" of productivity growth in backward countries, with some evidence showing that it accounts for more than $90 \%$, and even as much as $99 \%$, of the productivity of countries in the receiving end. ${ }^{4}$ Among evolutionary economists, on the other side, the importance of technology diffusion/adoption notwithstanding, the true engine of growth is (local) innovation, in a context where innovation is defined in a broader sense-as we explain below.

The controversial nature of this discussion, namely, the relative importance of foreign versus local technology as sources of economic growth, is illustrated not just by the fact that mainstream and evolutionary economics have different approaches to these issues - as seems evident from the disagreement that has arisen also among mainstream economists in this regard. ${ }^{5}$ Our point, however, is that the debate has been far more controversial between mainstream and evolutionary economics than within mainstream economics. For one thing, the evolutionary theory represents the radical alternative to the neoclassical paradigm regarding the emphasis on intertemporal optimization, the assumption of rational and foresighted individuals, the very notion of technology, and the proper role of the government in the economy. ${ }^{6}$ Thus, in trying to assess the economic contributions of foreign and local technology, we are faced with the concern central to the review in this paper: reasonable answers stem from premises grounded on contesting theoretical frameworks. The review below aims for a close examination of these theoretical issues.

\footnotetext{
${ }^{1}$ Previous contributions on the distinction of foreign and domestic sources of technology include Coe and Helpman (1995), Verspagen (1993) and Keller (2004), among others.

${ }^{2}$ For the neoclassical debate see, for example, Romer $(1993,1994)$. The evolutionary view is represented by, among others, Nelson and Winter $(1982,2002)$.

${ }^{3}$ Easterly and Levine (2001). The preeminence of technology, however, is by no means uncontested; see Jorgenson et al. (1987), Kumar and Russell (2002), and Jorgenson and Vu (2010), among others.

${ }^{4}$ Keller (2004), this figure refers to the comparison of estimates upon the relative productivity elasticity to foreign/domestic R\&D in a small sample of nine rich countries. Some counter-evidence is found in Bernard and Jones (1996).

${ }^{5}$ For example, Barro (1997), Pritchett (1997), Lucas (2000), Baumol (2002), Spence (2011), Phelps (2016).

${ }^{6}$ Nelson and Winter (2002).
} 
Let us pose in a more concrete way what we claim are the core contributions of this paper:

First and foremost, we aim to provide an integrated framework for understanding what economists from different backgrounds think technology is, and the relationship between technology and growth. The notion of technology, even in the narrow field of growth economics, usually reflects quite different meanings among different economists (e.g., productivity, artifacts, ideas, high-tech inventions, small innovations). ${ }^{7}$ Thus, to overcome the hurdle imposed on our review by conflicting definitions and to provide a more cogent scenario for analyzing the impact of technology on the growth process, it is necessary, in the first place, to put together the different concepts and interpretations of technology both from the viewpoint of the mainstream theory and the evolutionary theory.

Second, we use the above conceptual definitions of technology to elaborate indepth on the distinction between the economic impacts of adoption (of foreign technology) and (local) innovation, which is one of the key subjects creating majorif little promulgated - contention between mainstream and evolutionary economics. We discuss various arguments to show the contrast between the mainstream's prominence of technology transfer as a major engine of growth in backward countries and the evolutionary contention that the true driver of growth is (local) innovation instead-the ability to translate technology into new and ever-changing commercial applications - even if the latter takes place along major technology trajectories (steam engine, electricity, electronics, ICT, nanotechnology, biotechnology).

Our third contribution relates to the distinct policy implications of these competing views on the relationship between technology and the economy. In doing so, we discuss how the disagreement relates to contrasting theoretical assumptions with regard to, among other things, the idea that the economy is populated by rational "optimizing" individuals subject to the logic of price-competition, and the effectiveness of self-organizing markets to coordinate the economic activity, both of which result in competing interpretations about the proper role of government in matters of innovation policy. In particular, we argue that the policy implications of the evolutionary approach-most commonly related to the literature of the National Innovation Systems approach, which we narrow down to aspects of sponsorship, leadership and coordination - stand in stark contrast to those drawn from the mainstream analysis, which stresses ideas of distance to the frontier and the advantage of backwardness.

The paper proceeds as follows. Section 2 discusses the conceptual understanding of technology. Section 3 discusses the controversy between mainstream and evolutionary economics over the fundamental aspects of technology that positively affect the growth and catch up processes. Section 4 addresses the implications of this controversy in terms of the ability of backward countries to realize their advantage of backwardness. Section 5 elaborates on the distinct policy implications drawn from the contesting theoretical frameworks under discussion. Finally, Section 6 presents the usual concluding remarks.

\footnotetext{
${ }^{7}$ About the distinct connotations of technology, see Romer (1993, 1994), Lucas (1988), Fagerberg (1994), Schneider and Ziesemer (1995) and Fagerberg et al. (2010).
} 


\section{The economics of technology}

In spite of it being one of the most often cited concepts, the definition of technology receives only occasional attention in the economics literature. ${ }^{8}$ The customary practice is to relate technology to "something" that increases productive efficiency, offsetting the tendency of other factors (capital, labor) to yield decreasing returns. Starting from this relationship, most writers focus on the technology features that lead to sustained rates of growth over the long-run, and endeavor to find out whether, or to what extent, those features arise as a result of positive spillovers or purposeful entrepreneurship swayed by market incentives.

That endeavor has resulted in many-fold competing notions of technology, which paradoxically makes it clumsier, rather than simpler, to understand the actual aspects of technology that matter to boost economic growth. Even more crucial, it makes it harder to understand the role of technology in the attempt to explain the differences in economic performance across countries (e.g., differences in levels of income and income growth).

The view of technology as "something" that is primarily embodied in artifacts has played a major role in this debate for a long time. In fact, the embodiment notion remains center stage in the research, or at least part of the research, that explores the determinants and the economic impact of technology diffusion (e.g., the capital accumulation debate). ${ }^{9}$ Yet, many writers point out as well the significant impacts of disembodied technical changes, which are based on the argument that, even without changes in the quality/number of factors of production, efficiency gains might accrue by making a better use of the installed capacity. From this perspective, the allocation and combination of productive factors into their best possible use, rather than just overall accumulation, is the major technology problem that countries willing to grow need to address. ${ }^{10}$

So, even though in practice they denote different processes, "technological change", "technology progress", and "productivity" turn out to be used as interchangeable terms that stress the nature of technology as the ability to produce more output from a given set of inputs. From this perspective, a process of "machineautomation" aimed at the elimination of routine work, therefore enhancing higher

\footnotetext{
${ }^{8}$ Freeman (1994), Bernard and Jones (1996). Indeed, a safe definition of what technology is troubles scientists of all fields. Someone has defined it simply as "....anything that was invented after you were born..." and a whole branch of sociology has been devoted to the case of technology as a "social construct", a contention that technology is forged through the organization, functioning, and needs of the society at large. Mokyr (2014), has stated that "...the exact interaction between science and technology is a subtle and complex one, time-variant, and culture-specific."

${ }^{9}$ De Long and Summers (1991) provide evidence of a close relationship between investments in physical assets and economic growth; and Kumar and Russell (2002) hold that capital deepening explains most of the observed cross-country growth differences (84\%). The quality-adjusted capital method pioneered by Jorgenson is justified as an attempt to account for productivity contributions of embodied technology usually overlooked in conventional growth accounting (Jorgenson et al. 1987; Jorgenson and Vu 2010).

${ }^{10}$ McMillan and Rodrik (2012) point out that, for many developing countries, the technology problem of major importance is structural change: a process aimed to shifting resources from less to more productive activities/sectors of the economy.
} 
efficiency in activities that rely on repetitive processes, counts as much as a process that stress on productivity improvements through the hiring of extra and better qualified workers, or as much as a process that stress simply on the reorganization of the production activity.

In addition to these widespread notions, technology is featured also as a process of knowledge creation that occurs either through purposeful private R\&D activities in the business sector or through economy-wide investments in human capital (education). ${ }^{11}$ The contemporary consensus in growth theory views technology as "something" that improves productivity and hinges fundamentally on the creation of "ideas": blueprints that offset the curse of decreasing returns to capital, allowing the economy to obtain endogenous exponential growth. ${ }^{12}$

The reasoning behind the twist from the "machines view" to the "ideas view" is compelling: giving one laptop to one worker makes that worker more productive (provided they know how to use it), yet creating a new algorithm (e.g., to ease internet access) makes everybody better off. In the first case, the efficiency hinges on the number of laptops per worker; in the second, the use of the algorithm by one person does not prevent any other person from using the same algorithm at the same time. The efficiency, in this case, does not hinge on the number of ideas per worker but on the aggregate stock of ideas. ${ }^{13}$

One limitation of this perspective, however, is the widespread association of "ideas" exclusively with advanced scientific and technological endeavors at the frontier. Despite some debate and controversy whether income and income growth differences across countries are better explained by "objects gaps" or by "ideas gaps", the mainstream perspective is that less developed countries benefit the most from the diffusion and adoption of frontier technology. ${ }^{14}$

From the perspective of evolutionary economics, the major shortcoming in this analysis is the presumption that the acquisition and mastery of foreign technology are "automatic". In contrast, as Nelson (2008) points out, what the experience of many countries show is that significant improvements in the economic activity of less developed countries have resulted overall from the assimilation rather than the, however important, acquisition of new ideas and technology developed elsewhere. ${ }^{15}$ From this account, assimilation and then (local) innovation-understood in broad terms as the ability to develop new products and new ways of doing things in a localized context-is the crucial challenge for countries aiming to catching up. ${ }^{16}$ As we shall largely discuss later, the economics of innovation is not alien to the mainstream. ${ }^{17}$ In fact, both mainstream and evolutionary traditions retrieved their

\footnotetext{
${ }^{11}$ Romer (1993, 1994), Lucas (1988).

${ }^{12}$ Romer (1993), Jones (2005).

${ }^{13}$ Jones (2005).

${ }^{14}$ Romer (1994), Mankiw et al. (1995), Barro and Sala-i-Martin (1997), Grossman and Helpman (2001), Sachs and McArthur (2002), Parente and Prescott (2002).

${ }^{15}$ Pack and Nelson (1999), Nelson (2008).

${ }^{16}$ Nelson (2008), Fagerberg et al. (2010).

${ }^{17}$ See, for instance, Aghion et al. (2013), Lerner and Stern (2019).
} 
core ideas from earlier writings by Schumpeter, ${ }^{18}$ but the scope of the analysis is sufficiently different to deserve comparison.

The evolutionary approach to explaining the role of innovation in boosting economic growth holds that once producers have developed a variety of new products, a selection process takes place by consumers in the marketplace. The selection process involves substantial competition with other producers and determines whether or not the new products are going to be successful. The market success of a new product, however, is inevitably a temporary issue. Even if the new products that survive competition do well for the first generation, they may do less well for the second, and still less for the third, and so on. If they are not at least slightly modified, the "popularity" of the new products is a decreasing function of the time a product has been in the market. At length, the pressures of competition and the consumers' craze for the "new" compel producers to seek permanently newer market strategies and novel products. ${ }^{19}$ A similar emphasis as ours on the role of innovation is found in Baumol (2002).

This line of reasoning, according to which innovation-rather than simply the ability to produce more and cheaper-turns out to be the key to ensuring business survival, challenges the conventional "optimization paradigm". At the microeconomics level, rather than maximizing some well-known profits function, entrepreneurs are featured as "risk-takers" continuously striving to produce "new" in order to overcome competition and selection pressures. ${ }^{20}$ By extension, at the economy-wide level, rather than through the "optimal allocation" of factors, it is the ability to innovate what has proven important to keep productivity from declining.

Economics historians have shown that, virtually worldwide, the major upsurges of productivity are explained by the spread of inventions originated in leading countries, from the steam engine to the electronic circuit. ${ }^{21}$ But they point out also that the economic impact of the new technologies materialized mainly through the wide range of innovations reflected in countless commercial applications of those inventions, rather than through one-time productivity shocks. ${ }^{22}$ Thus, the compelling argument can be advanced that, as the discovery/invention of major technologies helps to resolve the productivity problem, the problem that remains is what to produce: how to take advantage of the production possibilities opened up by the new inventions. From this perspective, the process of economic growth is overall a reflection of the ability of entrepreneurs to use the most sophisticated technologies to produce innovative products aimed at creating or maintaining consumer demand.

\footnotetext{
${ }^{18}$ Schumpeter (1934, 1950). See Nelson (2008), Aghion and Howitt (2006).

${ }^{19}$ Nelson and Winter $(1982,2002)$

${ }^{20}$ According to Castellion and Markham (2013), innovation failure rates behind actual cases of success range up to $90 \%$ of the new products/processes launched — or even before they are actually launched — to the market.

${ }^{21} \mathrm{~A}$ well established fact in the literature is that most of the path-breaking technologies in use today are originated in just a few countries and spread to backward countries via trade, foreign direct investment and licensing channels Keller (2004).

${ }^{22}$ Schmookler (1966a, b), Dosi (2013), Gordon (2014), Phelps (2016).
} 
Yet, in spite of its importance, trying to encapsulate the notion of innovation is a cumbersome issue. For one thing, there is no way to separate neatly the distinct economic impacts of technology adoption and local innovation. Evolutionary economists themselves posit that innovation involves practices that are only "new in a given context" as there are many instances where it corresponds simply to the adoption or imitation of practices that have been used for a time elsewhere. ${ }^{23}$

Then, there is a striking amount of dimensions in which the innovation issue can be analyzed, including both supply and demand sides of the economy. ${ }^{24}$ Writers point out that innovation may be related with any improvements in logistics, distribution, marketing, and new business models, the main purpose of which is to increase productive efficiency-not necessarily to produce new goods. ${ }^{25}$ Innovation studies have extended the discussion from product, process, organizational, and marketing innovations to innovations resulting from emerging technologies, "open innovations" and "disruptive innovations", which clearly makes it harder to claim a fair academic understanding of the workings of this source of technology progress. ${ }^{26}$

In view of the above mentioned complex definitional issues, the need for a broad view of innovation, alongside the evolutionary way of thinking, seems warranted. ${ }^{27}$ From this perspective, innovation is an all-encompassing concept including any (localized) commercial applications of technology featured by the continuous improvement to production processes, inputs and outputs. But there is much, among other aspects, innovation is also seen from this perspective as a dominant strategy for producers in order to survive the pressures of competition and selection; and it is held to supersede the conventional emphasis on price competition emphasizing instead on the greater advantages of international competitiveness through differentiated products. $^{28}$

As is evident from the above discussion, the conceptual distinction between the economics of foreign technology and (local) innovation is in order if one wants to understand properly the workings of technology in explaining income and income growth differences across countries. Yet, we also need to understand the nature of the differences regarding the theoretical frameworks on which competing notions of technology are chiefly addressed. That is the focus of the next section.

\section{Technology and growth theory}

The theoretical understanding of the relationship between technology and income per capita differences across countries has spread both through models that stress the

\footnotetext{
${ }^{23}$ Nelson (2008), Fagerberg et al. (2010).

${ }^{24}$ Schmookler (1966a, b).

${ }^{25}$ Fagerberg et al. (2010).

${ }^{26}$ The proliferation of terms related with the notion of innovation is said to have surpassed the indicators and definitions in the Oslo Manual (Gault 2014).

${ }^{27}$ Nelson and Winter (2002); Nelson (2008); Fagerberg et al. (2010).

${ }^{28}$ Baumol (2002), Romer (1994).
} 
mechanism of growth and models that stress the mechanics of diffusion. The former stick to the premise that "one-size-fits-all" and explain the long-run dynamics of income and technology paying minor attention to cross-country interactions. Models of technology diffusion, on the other side, turn their attention to cross country interactions in order to analyze the benefits accrued to backward countries through the spread of technology from the frontier.

The key features that characterize both types of models have been amply documented in the literature. ${ }^{29}$ Here, we concentrate on a comparison between the neoclassical perspective (namely, growth models and models of technology diffusion) and the perspective offered by the evolutionary theory over the key aspects of technology that influence economic growth and the role of government in this process. Let us begin with the conventional approach.

The theory of growth In the seminal model of Solow, the technology parameter, A, was originally thought of as "something" exogenous that positively affects the amount of output per worker. Later, with the emergence of what we can refer to as early endogenous growth models (EEMs) and AK models, technology was thought of as an endogenous factor. ${ }^{30}$ The positive effects of technology on production, however, were not considered as an outcome of deliberate choices by individual producers but rather as unintended consequences of the aggregate level of technology (e.g., knowledge externalities). In the modern approach to the theory of growth, technology is fully endogenized as the outcome of purposeful investments by entrepreneurs to develop and accumulate knowledge in order to maximize profits. These are the so-called R\&D-based and ideas-based endogenous growth models. ${ }^{31}$

The latter class of models commands further distinction. First generation models (FGMs) are associated with the idea that technology leads to "persistent" and "increasing" rates of growth in the long-run. ${ }^{32}$ These models have been abandoned as a devastating consequence of the famous Jones' Critique and replaced by secondgeneration models (SGMs), a number of technically more appealing models that seek to explain what determines the observed empirical regularities of diminishing returns to technology investments. ${ }^{33}$ At present, SGMs split into the so-called semi-endogenous and product-variety Schumpeterian growth models. ${ }^{34}$

\footnotetext{
${ }^{29}$ See Snowdon and Vane (2005), pp. 579-659 for a comprehensive review.

${ }^{30}$ The EEMs classification includes many growth models that, through the 1950s, 1970s and 1980s, attempted to endogeneize technical progress; some examples are: the learning-by-doing approach of Arrow, the model of inventive activity of Shell, the two sectors models of Uzawa, and Phelps, and the Keynesian approach of Kaldor and Mirless. These developments greatly influenced the development of the "new growth theory". See Romer (1986), and Schneider and Ziesemer (1995), for reviews of those earlier contributions.

${ }^{31}$ Romer (1994), Ha and Howitt (2007), Jones (2005).

${ }^{32}$ Examples include models of product variety and quality ladders, i.e., with an increasing number or a higher quality-set of intermediate inputs (Romer 1994; Grossman and Helpman 2001).

${ }^{33}$ Jones (1995). The critique points out that the predictions of FGMs are inconsistent with the empirical evidence, namely, while the resources devoted to R\&D trend increasingly upwards in most developed countries, productivity growth rates do not follow a similar trend.

${ }^{34}$ Jones (1995, 2005), Ang and Madsen (2011), Aghion et al. (2013).
} 
The semi-endogenous growth models hold that an increasing amount of resources is needed to compensate for the diminishing returns to knowledge accumulation and to keep the economy growing. As the production of technology is some function of the number of researchers, which in turn is some share of total population, it leads to the implication that, in the long-run, economic growth stems from a country's (population) size. A further implication of these models is that economic growth is unresponsive to taxes and other public interventions as the impact of these policy instruments vanishes asymptotically.

The key assumption in the class of Schumpeterian growth models, on the other side, is that there is a process of creative destruction that ends up reducing the preeminence of increasing returns. The effectiveness of $R \& D$ investments vanishes as the economy expands because new innovations are more costly due to their increasing complexity. In addition, the proliferation of product varieties implies that the investments in R\&D spread each time over a much larger and slightly differentiated set of products. Unlike the semi-endogenous class of models, the Schumpeterian models hold that long-run growth is highly responsive to policy incentives. Because the success of investments in innovation is uncertain, it requires incentives for firms to devote more resources to $\mathrm{R} \& \mathrm{D}$ activities.

To sum up, the ongoing debate between semi-endogenous and Schumpeterian growth models demonstrates (again) that-even within mainstream economics- the nature of technology progress, its impact on economic growth and the role of public policy in this regard are not yet safely established. ${ }^{35}$ The competing but contrasting theoretical interpretations of these issues has raised skepticism among many economists about the use of technology policy as a tool to foster economic growth, and the lack of clear empirical support for either theory further the grounds for the disbelief. ${ }^{36}$

Models of diffusion The critical advance of the endogenous literature over the earlier neoclassical model was the understanding that the production of technology hinges not only on market incentives - namely, the ability of investors to capture (at least some of) the returns on their investments-but also on policies and institutions that provide further incentives and fix the gap between social and private returns. ${ }^{37}$ Yet, when it comes to the analysis of the different impacts of foreign and local sources of technology, the dominant theoretical framework is associated with models of technology diffusion. ${ }^{38}$

\footnotetext{
${ }^{35}$ Note, for instance, the contrasting views in Jones (2005) and Romer (2000), with regard to the use of subsidies to encourage innovation. See also Kremer (1998) on the use of patent rights in light of distortions generated in the pharmaceutical industry, and the Boldrin and Levine (2002) suggestions to restrict or eliminate patent rights altogether.

${ }^{36}$ See Jones (1995, 2005), Ha and Howitt (2007), and Ang and Madsen (2011), for empirical tests of these models.

${ }^{37}$ Ziesemer (1991, 1995).

${ }^{38}$ Barro and Sala-i-Martin (1997), Benhabib and Spiegel (2005), Acemoglu et al. (2006), Aghion et al. (2013), among others.
} 
The widespread understanding driven by these models is that the key technologies that matter to generate economic growth are invented at the frontier and spread to backward countries through diverse channels (imports of machines and equipment, learning by exporting, foreign direct investment, licensing). This line of reasoning became popular under the hypothesis of advantage of backwardness which is at the core of the Schumpeterian-based models of distance to the frontier introduced above. ${ }^{39}$ Yet, a similar line of reasoning is found in other theoretical models, e.g., the so-called North-South models, ${ }^{40}$ and leader/follower models. ${ }^{41}$

In this perspective, the potential of backward countries to grow and catch up is influenced by their absorptive capacities. A considerable research effort on this front has been on human capital issues, ${ }^{42}$ and the institutional (free market) conditions that influence private investment decisions. ${ }^{43}$ For many economists that build on this tradition, the combination of technology diffusion with indigenous absorptive capabilities is a crucial part of the explanation of why there are some countries that manage to grow and catch up and others that fail to do so. ${ }^{44}$

Another distinctive feature of models of technology diffusion is their sequential view. From this perspective, technology progress is considered to go from adoption and imitation in early stages of development to innovation in later stages, each stage warranting a different type of intervention. For example, non-competitive arrangements (monopolistic rights) and active government intervention (trade barriers, selective investments subsidies, directed credit programs) are seen as consistent strategies to encourage risky investments during the adoption stage but unsuitable to encourage innovation, which is regarded as an activity that hinges on limited government intervention, market-conforming policies, and strong market competition. ${ }^{45}$

There is also another kind of models that address issues of diffusion from a "pure economics" perspective-hence without explicit reference to institutional and policy intervention features. ${ }^{46}$ Yet, discussing those models is not in our scope here. Instead, we examine below the main theoretical objections that have been raised by the evolutionary approach to the various analytical approaches outlined above.

The evolutionary approach Mainstream economics sticks to the analysis of marketdetermined equilibrium solutions where rational, perfectly flexible, and foresighted

\footnotetext{
${ }^{39}$ The hypothesis of advantage of backwardness dates back to Gerschenkron (see Acemoglu et al. 2006 for a review). For a recent assessment, see Aghion et al. (2013).

${ }^{40}$ Acemoglu (2014).

${ }^{41}$ Stiglitz (2014).

${ }^{42}$ Lucas (1988, 2009), Romer (1993), Benhabib and Spiegel (2005), Stokey (2012).

${ }^{43}$ Hall and Jones (1999), Jones (2005), Acemoglu et al. (2006). Accordingly, technology transfers and thus long-run growth is influenced by trade policies (trade openness), the provision of infrastructure and financial markets, policies that affect investment (taxes, subsidies), fiscal stability, property rights, and the maintenance of law and order Barro (1997).

${ }^{44}$ Parente and Prescott (2002), Acemoglu et al. (2006), Stokey (2012), Aghion et al. (2013).

${ }^{45}$ Acemoglu and Robinson (2000), Sachs and McArthur (2002), Acemoglu et al. (2006), Zilibotti (2008), Stokey (2012).

${ }^{46}$ Benhabib and Perli (1994), Benhabib et al. (2014).
} 
maximizing individuals make choices over clearly defined scenarios. At the microeconomic level, it is assumed, the decentralized actions of optimizing producerseither under perfect or imperfect competition settings-ensure that all profitable options are fully exhausted given a set of constraints; and these micro-foundations form the basis for the analysis of all macroeconomic issues, including the relationship between technology and economic growth.

Evolutionary theorists question the ability of markets to generate optimal solutions in the first place, and then the reasonability of the assumptions held in their support. Unlike in the neoclassical case, in the evolutionary approach there are not well defined opportunity sets. The relevant knowledge is split among different actors (consumers, producers, businesses, public organizations, universities) so that when individuals make choices, they are mostly in possession of incomplete information, unaware of the best alternatives, if any. In addition, they are also influenced by their own beliefs and by contextual circumstances (culture, society, institutions). In conditions of uncertainty, the economy expands as some producers make profitable decisions - even if not optimal—or contracts as they make unprofitable ones. In sum, contrary to the tenets of the conventional analysis, bounded rationality and imperfect foresightedness limit the ability of individuals to reach optimal solutions. ${ }^{47}$

The evolutionary analysis of technological change and economic growth is one of the most important lines of research in this approach. It holds that the entrepreneurs' ability to make optimal choices is constrained by lock-in and path-dependence effects. The strong heterogeneity in the market implies that some firms are better than others at acquiring/exploiting technological opportunities. Even the best performers would probably prefer to stick to known routines and technologies for long periods of time as the adjustment to new conditions, and the economic benefits of doing so, can be realized only when the economic system as a whole evolves and adapts to those conditions. Hence, evolutionary economists point out that, rather than on continuous equilibrium, along the process of technological change entrepreneurs are permanently out-of-equilibrium, and adjust to changing conditions only sporadically. ${ }^{48}$

In addition, rather than seen innovation exclusively as an activity of leading industries that invest intensively in $R \& D$, evolutionary economists hold that, whether in high-tech or in low-tech activities, all entrepreneurs are in essence innovators making choices in conditions of uncertainty: their challenge is to use technology efficiently to produce new products (rather than more of the same products). In order to meet the consumers' search for the "new" and overcome the pressures of competition, entrepreneurs need to develop "new varieties" of their products permanently-each variety slightly differentiated not only from those of other firms but also from previous versions of their own. ${ }^{49}$

\footnotetext{
${ }^{47}$ Nelson and Winter (1982, 2002). See also Simon (1979) for a general discussion of bounded rationality. See Thaler (2015) for a discussion of bounded rationality in consumers' decision making.

${ }^{48}$ Nelson and Winter (2002), Nelson (2008). See also Arthur (1994), Arthur et al. (1997).

${ }^{49}$ Lundvall (2007) pp. 109(ss), citing Arrow, pinpoints that, indeed, innovation is not suitable for mainstream ways of thinking of rational and maximizing individuals, as "...innovation has as its most
} 
Therefore, whereas the importance of high-tech and the economics of diffusion are not contested, in the view of evolutionary economists low-tech innovations are a substantial source of returns and growth at the economy-wide level. ${ }^{50}$ Lowtech innovations are frequently - though not necessarily always-defined as non R\&D-based innovations focused on solving relatively simple problems (location, marketing and logistic strategies, new designs, new product concepts); they take place often - though not necessarily always - in low skill labor sectors (food, textiles, footwear, furniture) and generally involve a wide range of activities (sales, acquisitions, communications)..$^{51}$

Broadening the concept of innovation along these lines, which is one of the tenets of the evolutionary theory, certainly has implications for the way we think of the role of technology on the economy. In particular, regarding the interaction between (local) innovation and technology diffusion. Evolutionary theorists highlight the view that "innovation" may be defined simply as any "new way of doing things in a localized context". ${ }^{52}$ But that definition, of course, raises the question of why (and how) to separate the growth effects of local and foreign technology in the first place.

Our own interpretation of the extensive evolutionary literature in this regard is that, while technology diffusion brings in new ways of production - which fundamentally allow the production of more and/or cheaper goods - or even ideas on new products, new forms of organization and so on, those benefits are not "automatic", deliberate choices are necessary to enhance the economic impact of the introduction of the new technology. Technology diffusion is important to the extent that high-tech sets technology trajectories or "technological regimes" that, in the end, spread and become common to all countries alike. But realizing the possibilities of the new technology is something that depends overall on the ability to produce innovations along those trajectories, regardless whether these are overall low-tech innovations.

There is a considerable body of literature dealing with such subjects as the product life-cycle, induced innovations, localized technological change, social capabilities, technological capabilities, and absorptive capacities that has been put forth to analyze a variety of issues affecting the innovative potential or, at least, the technological upgrading of the business sector in backward countries. Such issues include aspects as: factors endowment, technical know-how, the social-cultural context, public policies, institutions, political competition, and so on. ${ }^{53} \mathrm{~A}$ detailed analysis of these

\footnotetext{
fundamental characteristic that it gives rise to something that is not known in advance - and it is not possible to apply the principles of rational choice if the choice set is not defined in advance." See, also, Nelson and Winter (2002) and Soete et al. (2010).

${ }^{50}$ Nelson (2008).

${ }^{51}$ Herstatt and von Hippel (1992), Scott (2006), Hirsch-Kreinsen (2008), Foray and Lissoni (2010), Huang et al. (2010), Stephan (2010), Som and Kirner (2016). Low-tech innovations are now the subject of increasing research activity and policy attention. For example, in innovation surveys, they are deemed to comprise technologically new or significantly improved products (goods and services) and processes, such as the design of new products, the introduction of new equipment, the logistic and marketing to introduce new products into the market, or to create a demand where it did not exist before. See the Bogota Manual RICYT (2005), and the Oslo Manual OECD (2005).

${ }^{52}$ Nelson (2008), Fagerberg et al. (2010).

${ }^{53}$ Lin et al. (2011), Acemoglu (2014), Cohen and Levinthal (1989), Snowdon and Vane (2005), pp. 579659.
} 
strands of the literature is beyond the scope of this paper. Yet, it is worth noting that their focus-however commendable - do not provide a description nor an interpretation of the role of entrepreneurship, nor of the ever-changing contextual conditions that feature in the discussion of evolutionary economics.

An alternative literature that has developed alongside the evolutionary theory described here is the so-called national innovation systems approach, which is deemed to cope with all market and non-market interactions that play a role in fostering innovation. ${ }^{54}$ From this perspective, the ability to catch up technologically and economically hinges on the ability of countries to organize the innovation activity to the widest economic extent. In what follows, we refer to this perspective as the NIS framework.

The NIS framework may be held to bring in two main objectives. The first is to provide a language aimed at the description and comparison of national institutions, competencies, and incentive structures that play a role in generating and spreading technological knowledge (as a resource), facilitate learning (as a process), and boost innovation (as a product). The second is to shape an alternative view of the theory of technical change, which seeks to explain the determinants and nature of innovation as the major economic engine, and the way the government (or the State at large) may enhance the innovation process in order to influence economic growth. ${ }^{55}$

The contentions of the evolutionary economics of technology change and innovation, and the literature developed under the NIS framework, have received scarce to no mention in the mainstream growth theory thus far. ${ }^{56}$ However, the converse is also true with the evolutionary and NIS literatures ignoring, or downplaying, the neoclassical views on technology progress and technology policy. ${ }^{57}$ We now briefly review what, in our view, determines this mutual neglect.

One area of disagreement, as we have mentioned above, is on matters of government intervention. The conventional mindset is driven by ideas of political liberalism from classical economics. In this tradition, a limited role of government is sine qua non for economic prosperity. Thus, along the provision of public goods and the enforcement of free-market institutions (property rights), the most prominent role for the government in the neoclassical perspective is to provide market-based incentives to encourage the entrepreneurs' decision-making process. The NIS framework, by contrast, holds - on the basis of looking at the historical evidence and the analysis of numerous country case studies - that substantial intervention is needed to encourage the appropriate level of innovation and create/enhance competitive advantages overall when it comes to competition in the international market. ${ }^{58}$

Another crucial reason for the disagreement is associated with the lack of techni$\mathrm{cal} /$ mathematical sophistication in the NIS framework, which mainstream economists

\footnotetext{
${ }^{54}$ Nelson (1993), Freeman (1987, 1995), Lundvall (2007), Soete et al. (2010).

${ }^{55}$ See Lundvall (2007). See Wirkierman et al. (2018), for a recent review.

${ }^{56}$ To the best of our knowledge, the evolutionary arguments on innovation, economic growth, and catch up receive scarce mention only in Romer $(1993,1994)$, which regards the evolutionary approach as sensible though flexible and informal. See Stiglitz (2014) for a recent overview and discussion.

${ }^{57}$ Nelson (2008), Dosi and Nelson (2010), Fagerberg et al. (2010), Soete et al. (2010).

${ }^{58}$ Freeman (1995) and Lundvall (2007).
} 
deem necessary to examine the most substantive questions on long-run growth. ${ }^{59}$ The NIS analytical approach is largely based on nontechnical accounts of the nature and determinants of innovation, and the impacts of innovation on economic growth. This feature bears a resemblance to the evolutionary approach which, as pointed out by one of its critics, 'requires neither price-taking nor explicit maximization for its description of market outcomes' - a method referred to as Appreciative Theory. ${ }^{60}$ Notice, however, that, unlike the critique, formal modelling is a well-established practice in evolutionary economics. ${ }^{61}$ It is in extending these developments to study the NIS approach to innovation that there is an open area for future research.

It is apparent, on the other side, that the core advantage of the NIS approach is that it provides a way to organizing numerous types of innovation policies and innovation related strategies that have been suggested in the literature; ${ }^{62}$ and, in more general terms, it is a framework suitable for the analysis of innovation under alternative policy systems. ${ }^{63}$ Therefore, it is instrumental to overcome the "pure economics" analytical approach that features prominently in mainstream economics, and also to complement the literature on the institutional barriers that hinder entrepreneurship in developing countries. ${ }^{64}$

Yet, in our view, neither the mainstream approach nor the evolutionary nor the NIS perspective may be regarded individually a complete account of the key issues that matter in the academic understanding of the relationship between technology and economic growth. Instead, each approach can at best be seen as offering a partial understanding of the different aspects that need to be considered when we think of the economics of innovation. The inter-temporal optimization and dynamic analysis that characterize the mainstream approach is certainly suitable to understand the long-run impacts of technology policy. In that sense, this approach overcomes the static nature of economic analysis characteristic of the NIS framework.

\footnotetext{
${ }^{59}$ See, for instance, Romer $(1993,1994)$.

${ }^{60}$ The critic is from Romer (1993). The Appreciative Theory overturns the emphasis on equilibrium optimization, focusing instead on the qualitative assessment of numerous in-depth country case studies (Nelson and Winter 2002; Nelson 2008). NIS systems are considered highly localized, and with large variation across countries, which implies that any attempt to perform quantitative or aggregate analyses is misleading. For example, in some cases, government interacts mainly with large firms (e.g., chaebols in South Korea, keiretsu in Japan), while in others it builds upon networks of small firms (e.g., the Italian industrial districts). See Nelson (1993), Freeman (1995), Lundvall (2007), Soete et al. (2010) and Stiglitz (2014) for further references.

${ }^{61}$ See the sequence of publications on "The economy as an evolving complex system": Anderson et al. (1988), Arthur et al. (1997), Blume and Durlauf (2005). See also Safarzyńska and van den Bergh (2010). A variety of growth models build on evolutionary perspectives: Medio and Negroni (1996), Silverberg and Lehnert (1996), Verspagen (1993), Silverberg and Verspagen (1995), Silverberg (1997). See Nelson and Winter (2002) for further references.

${ }^{62} \mathrm{See}$, for instance, the large number of papers presented in the proceedings of Innovation Policy and the Economy sponsored by the National Bureau of Economic Research-NBER Lerner and Stern (2019). The aims of numerous public peripheral agencies illustrated by Breznitz et al. (2018). See also Wirkierman et al. (2018).

${ }^{63}$ Hall and Soskice (2003)

${ }^{64}$ Barro (1997), Parente and Prescott (2002), Acemoglu and Robinson (2000), Lin et al. (2011), Stokey (2012)
} 
However, the "broad" view of innovation stressed in the evolutionary approach, and the institutional-comparative focus of analysis that has become customary under the NIS framework, are also highly relevant. In the first case, to better the academic understanding of this research subject. In the second, to stress the importance of the complex network of interconnected institutions related to the production of innovations at the national level. Furthermore, the NIS seems a more plausible framework to represent the systemic nature of innovation, which to a large extent involves nonmonetary transaction between parts of the system and hinges largely on the capacity of the government to lead the innovation process beyond the fixing of market failures.

In summary, a unified theoretical framework, taken into account elements of each of these approaches, seems warranted if one is really interested in explaining the fundamental role of technology as an engine of "perpetual" growth, and in providing sound justification for policy interventions in this regard. Below, we briefly reflect on the main implications of our assessment to enhance the understanding of the actual benefits of economic backwardness.

\section{Advantage of backwardness revisited}

One of the most controversial elements mentioned above is undoubtedly the emphasis on a government-led innovation approach. ${ }^{65}$ NIS economists agree that such considerations as imperfect information, incomplete, imperfect or total absence of markets (e.g., patent protection, risk finance, skilled labor), which hinder the benefits of the investment, are major "market failures" that hold back innovation. But, as they point out, the ultimate problem with the promotion of innovation is associated with its "systemic" nature. 66

As many writers in the NIS tradition point out, even if property rights are well defined, human capital (education) and (efficient) financial markets are in place, and policy tools (subsidies/taxes) are available, innovation may still be precluded by the fact that the government, the education system, the entrepreneur and the investor are all different parties. In these circumstances, it is argued, subsidies and property rights notwithstanding, there may still be low investments in innovation if, for instance, financial agencies are efficient but still reluctant to support certain projects, or if they are more risk-averse than entrepreneurs themselves are, or if there is a sound education system which however falls short of enhancing the qualifications that the production system requires. ${ }^{67}$ Moreover, while the absence of property rights discourages the production of new knowledge, patents reduce innovation by reducing

\footnotetext{
${ }^{65}$ From the mainstream viewpoint, government intervention is not (always) warranted (LeGrand 1991; Stiglitz 2008). The problem, as suggested in early research in this front, is that although intervention might be instrumental to address some market failures, it may, as well, generate higher welfare losses if the failures are exogenous to the market which, therefore, do not justify the need for policy intervention as, in that case, there is not safe guarantee of reaching superior Pareto solutions Bullard and Butler (1993).

${ }^{66}$ Hall and Rosenberg (2010), Soete et al. (2010).

${ }^{67}$ Hall and Lerner (2010), Mokyr (2010), Soete et al. (2010).
} 
the spread of knowledge. ${ }^{68}$ And many other distortions persist even under perfectly competitive markets, which are associated to "rent-protecting-activities" followed by business firms to avoid knowledge leaking/sharing and thus reduce the potential risks of product imitation and market competition. ${ }^{69}$

Accordingly, the systemic nature of innovation justifies the need for active government intervention to further the different elements that could incentivize the production of innovations, namely, a close interaction between public and private sectors to initiate, import, modify and diffuse new technologies; financing mechanisms funded by the public sector when and if other sources of venture capital are not available from the market, or if the financial system is poorly developed; and the coordination of complementary innovation-related activities conducted by education and training institutions, universities and technical institutes, public institutions, industry associations, and so on, and also for the enforcement of networking mechanisms, collaboration and partnerships between production sectors upstream and downstream.

Hence, with the above assessment in view, in the NIS framework the benefits of being backward hinge on three fundamental premises:

(i) the national technology and innovation landscape depends largely on activities and projects initiated or pioneered by the government which later spin off to public-private partnerships, universities and business enterprises that commercialize the research outputs;

(ii) government financing plays a large role in fostering innovation at all levels, particularly when and if other sources of financing (banks, stock markets) are risk-averse, less inclined to finance projects that carry out significant uncertainty;

(iii) innovation is positively affected by the systemic coordination of innovative activities carried out not only by private business entrepreneurs but also by universities, technical institutes and the government itself, regardless of whether pecuniary transactions are involved or not.

All of these conditions, namely, government leadership, government sponsorship and government coordination of the innovation system, have been generally found in a wide range of country case studies that explore the association between innovation and economic growth. ${ }^{70}$ In particular, those studies support the view that innovation is an important way to enhance international competitiveness and technology specialization patterns other than through conventional price mechanisms. In turn, among the various arguments that are highlighted to bolster the role of government in this regard, one is that innovation itself is a source of comparative advantage. It is noteworthy that this subject has received lots of attention in micro and macro-economics

\footnotetext{
${ }^{68}$ Kremer (1998), Boldrin and Levine (2002).

${ }^{69}$ Dinopoulos and Syropoulos (2007).

${ }^{70}$ Nelson (1993), Kim (1993), Fagerberg (1994), Fagerberg and Verspagen (2002), Freeman (1987, 1994, 1995, 2004), Lundvall (2007), Hall and Lerner (2010), Huang et al. (2010), Foray and Lissoni (2010).
} 
literatures that, therefore, challenge the mainstream view of technology as a global "pool of ideas" (from which backward countries can draw and benefit) as, for one thing, such "idealized" view overlooks the limits of knowledge diffusion posed by the, however logical, reluctance of first stage innovators to release their secrets. ${ }^{71}$

Thus, in our view, the NIS approach has developed as an alternative to the policy framework traditionally advocated in the context of the advantage of backwardness, namely, the emphasis on market driven developments and institutions that enhance backward countries' absorptive capacities (human capital, infrastructure investments, trade openness). ${ }^{72}$ To repeat, the most striking implications of the NIS literature for the debate upon the proper role of government in the economy is that, along-or even beyond - the widespread emphasis on such issues as cheap labor, tax reductions, currency devaluations, and absorptive capacities, the ability to overcome backwardness hinges to a large extent on innovation and, therefore, it is determined by the ability of backward countries to enforce the innovation system. ${ }^{73}$

Furthermore, rather than abiding for the usual tenet that innovation becomes an issue only at advanced stages of development, ${ }^{74}$ the NIS framework focuses on the analysis of all factors that influence innovation regardless the stage of development or the business cycle. ${ }^{75}$ Within this framework, the point to stress is that competition and integration in global technology markets are choices that require discretionary policy strategies at the country level in order to overcome the limitations imposed by the economy's endowments. The latter has been an everlasting subject of concern in development studies where the theory has been unable to offer a policy alternative to conventional "price incentives". Empirical research has shown that, whenever an agenda to upgrade the innovative landscape in backward countries is lacking — as they choose to follow conventional theoretical prescriptions instead, knowledge-intensive production activities tend to concentrate in the most advanced economies, whereas capital and labor-intensive activities are outsourced to countries that have the cheapest factor prices. ${ }^{76}$ While the catching-up potentials associated to the conventional strategy are limited, countries that have followed an explicit NIS agenda have been much more successful. ${ }^{77}$

\footnotetext{
${ }^{71}$ Dinopoulos and Syropoulos (2007) analyze how some strategies to protect property rents (patents, infringement litigations, delays in the introduction of new products, and so on) discourages innovation. Hobday (1995) points out that, in order to protect technology secrets, original R\&D tends to concentrate in-rather than outside-headquarters.

${ }^{72}$ Romer (1993, 1994), Grossman and Helpman (2001), Keller (2004), Lucas (2009).

${ }^{73}$ Lundvall (2007).

${ }^{74}$ Barro and Sala-i-Martin (1997), Sachs and McArthur (2002), Acemoglu et al. (2006), Aghion et al. (2013), and Lee (2013).

${ }^{75}$ Mazzucato and Semieniuk (2017).

${ }^{76}$ See Baldwin (1971), Madsen et al. (2010), and Nishioka (2013). See also the map of export trends in Hausmann et al. (2011). Lall (2000), shows that, as of 1998, just 10 countries accounted for over $80 \%$ of total exports worldwide, and this share rose with technological sophistication to reach $96 \%$ for the top 10 exporters of high technology products. By contrast, the share of world exports has declined for low-tech products, i.e., from $43 \%$ to $26 \%$ between 1985 and 1998 for resource-based and primary products.

${ }^{77}$ Freeman (1987, 1995), Nelson (1993), Kim (1993), Lundvall (2007).
} 
The discussion above has non-trivial consequences for the analysis and interpretation of the technology policy and development strategies followed by many countries worldwide. However, we need to recognize that, in more general terms, what is essential is not the "NIS framework" itself but rather the method of analysis. There are other literatures which, though they are not based on the NIS framework, push in the same direction and reach similar conclusions: appropriate interventions by the government are an important element to encourage private investments in innovation and knowledge sharing at the economy-wide level. ${ }^{78}$ For space reasons, an in-depth analysis of these NIS-like strands of the literature is not in the scope here.

Summing up, the central analytical message coming from our discussion above is that there is more to the innovation policy than the conventional "market incentives" contained in the mainstream theory, which is a line of investigation that warrants indepth research. For one thing, the fact that there are, still currently, many countries that tend to privilege adoption over innovation policies relates to a view consistent with the mainstream tenet that increasing economic growth hinges on technology transfer, for which a focus on typical market incentives and absorptive capacities suffice. By contrast, countries that seriously embrace and implement the NIS framework aim for a policy stance that relies more on government innovation related activities that have gained increasing recognition in the context of the development policy at least since the 1980 s. ${ }^{79}$ Below, we analyze the main policy implications that derive from the later approach.

\section{Policy implications}

The debate on the proper role of government in the economy is an old question that goes back to Adam Smith (1776) himself. However, asking it is still warranted, because the role of government is one of the important policy questions-if not the most important-whenever economists deal with issues of growth and catching up. ${ }^{80}$

The mainstream suggestion to restrain government intervention is based on premises that are well known-namely, that intervention reduces the efficiency of the price system and provides opportunities for corruption practices (rent-seeking). The strong preference for market solutions is stressed even in situations where the theory recognizes a role for the government: public expenditures in education, R\&D programs and infrastructure (roads, airports, public services), as the following quote reflects

...A lot of people see endogenous growth theory as a blanket seal of approval for all of their favorite government interventions, many of which are very wrong-headed. For example ... Infrastructure ... should be provided in the same way that we provide other physical goods, with market incentives and strong

\footnotetext{
${ }^{78}$ Wade (1996), Kasahara (2004), Cimoli and Hofman (2010), Lin et al. (2011), Stiglitz (2014).

${ }^{79}$ Soete et al. (2010), Lin et al. (2011).

${ }^{80}$ See, for instance, Stiglitz and Heertje (1989), Lin et al. (2011).
} 
property rights. A move towards privatization of infrastructure provision is exactly the right way to go. The government should be much less involved in infrastructure provision. ... Another is the notion that the government should directly subsidize particular research programs to produce particular kinds of ideas. If you compare that mechanism with the mechanism of subsidizing human capital and letting the market mechanism allocate where the human capital goes and what ideas get developed, the human-capital-based approach works better. $^{81}$

It seems apparent that policy makers influenced by these ideas-mainly in backward countries-would tend to design and enforce policies and institutions that stick to the efficient market hypothesis and, therefore, they would prefer to pursue technology policies that rely on measures to favor the attraction of foreign technology, capital and ideas using price signals (e.g., taxes, subsidies, low wages) but avoiding other ways of intervention to boost technology and innovation. The NIS framework instead, as we have insisted above, bears support to a broader role of the government to lead the innovation process, which, however, is not a plea for the State to replace the market as long as the ultimate goal in this framework is to boost rather than discourage private sector innovation.

Thus, whereas NIS researchers are amenable to conventional remarks to promote technical change and economic growth, namely, economic stability, trade openness, property rights, market competition and price incentives (taxes, subsidies, and so on), they do not accept that these elements fully exhaust or describe everything that the innovation policy needs to consider, nor the way it has been conducted in countries at the frontier, and this view has received increasing support from numerous innovation studies. ${ }^{82}$ Those studies hold that active public action-in a way that closely resembles our description of the NIS framework-is a widespread practice to foster innovation and growth in industrialized countries and countries that have succeeded to catching up. Therefore, the immediate question that arises here is: what can backward countries learn from those experiences?

In attempting to answer such a question, let us elaborate upon a more detailed discussion of the main mechanisms of the NIS framework that we have summarized earlier into three crucial aspects, namely, sponsorship, leadership and coordination.

\subsection{Sponsorship}

Financial support to private business innovation touches on many standard arguments of "failures" in the financial market, as well as on issues of financial regulation, monetary policy, and more generally, macroeconomic stability. However, as we discussed earlier, it is generally acknowledged that innovation activities are hardly financed in competitive market settings. The NIS argument, therefore, is that, beyond fixing market failures, innovation requires risk capital that private innovators are generally

\footnotetext{
${ }^{81}$ Snowdon and Vane (2005), pp. 690, Interview with Paul Romer.

${ }^{82}$ Nelson (1993), Freeman (1995), Lundvall (2007), Nelson (2008), Mazzucato (2013), Mazzucato and Semieniuk (2017), Breznitz et al. (2018).
} 
unable to incur, and traditional financial institutions frequently have no incentive to provide.

In this context, the sponsorship mechanism entails a broad range of public activities and programs designed to fund private innovation initiatives. This includes the direct financing of basic research, scientific projects or scientific institutions (through fellowships, grants, awards) and government procurement expenditures (the government acting on the demand side) that allow investors to bypass financial restrictions and, therefore, have a direct impact on the technology investments of the business sector. ${ }^{83}$ Research in this field has demonstrated that public sponsorship has been a widely used mechanism through the entire innovation chain and also to create new technology landscapes regardless conventional business cycle considerations. More noticeable, the research has illustrated a role of public finance that, beyond conventional "fixing market failures" considerations has been purposefully used to provide large amounts of risk capital to public and private ventures, to achieve pre-established technological goals, and to shape and create new markets. ${ }^{84}$

In the major OECD countries the financing of innovation through public channels has a long history as governments in general have supported the view that innovation commands the use of risk capital. As Mokyr (2010), pointed out in terms of the financing of innovation: 'it is clear that there [is] more than one way to skin [the] cat,' and activist governments have over time financed innovation activities through variegated means, including investment funds that are guaranteed or assigned directly by the government in soft conditions, tax reliefs, exemptions and deductions, tariff protection, non-payable allowances. ${ }^{85}$ Noticeably, in spite of the widespread criticism related to the "picking-winners" problem, in many cases these activist interventions are program or sector specific.

In contrast, innovation financing mechanisms are, in general, more weakly institutionalized in backward countries. Along the obvious issue of resource constraints, the lack of financing schemes in this regard seems to be an issue widely dominated by the fact that the theoretical justifications to do so are virtually absent from the received theory and program frameworks adopted by these countries as part of the conditions set by international financial institutions and organizations to provide financial packages (loans, debt reliefs, development aid). ${ }^{86}$ Of course, the use of public finance to encourage business innovation is a highly controversial issue both in academic and political circles, and the discussion has been strongly influenced by corruption practices that are not unique but certainly more frequent in less developed countries.

On the other side, contrary to popular beliefs, in most developed countries public financing to innovation is not exclusive to high technology projects, namely, general purpose technologies (electricity), mission oriented State investments (exploration of outer space, climate change) or investments in pioneering fields (nanotechnology, biotechnology). On the contrary, the public sector has been a crucial source of patient

\footnotetext{
${ }^{83}$ Cohen (2010), Foray and Lissoni (2010), Stephan (2010).

${ }^{84}$ Mazzucato and Semieniuk (2017), Breznitz et al. (2018).

${ }^{85}$ Hall and Lerner (2010), Mokyr (2010), Mazzucato (2013).

${ }^{86}$ Dreher (2009).
} 
finance in multiple business sectors (agriculture, food, electronics, medicine, transport). ${ }^{87}$ This is an important insight for policy making in backward countries where small, or low-tech, innovation projects-which as we already pointed out generally have large economic impacts-frequently do not fit neither the stock market's nor the commercial banks' criteria for commercial credit or other forms of financing. ${ }^{88}$

The widespread reluctance of financial markets to sponsor innovation projects unless proper guarantees (collateral assets) and/or convincing cost-benefit analyses are fulfilled provided, in the past, quite a generalizable argument for the development of venture capital markets instead. ${ }^{89}$ But, however important, private venture capital markets are not a sufficient condition to ensure that financial resources are efficiently provided to support innovation, particularly in low-tech activities. First, venture financing, remains unavailable for the firms that need it more (startups). Second, venture financing is frequently a function of the stage of development of a new product or process. Third, more often than not, venture financing by private investors depends on the condition that innovators are worthy of receiving third-party funds (in which case, public funds and publicly guaranteed finance turn out to be the most obvious sources). These deficiencies are not unique but still more evident in backward countries given the small scale or actual absence of venture capital markets in those countries..$^{0}$

It is worth noting that the broad practice of sponsorship in countries at the frontier and countries that have managed to catch up is broadly documented, namely, the National Science Foundation and the Small Business Innovation Research Program in the US, the Small Business Research Initiative and the Medical Research Council in UK. ${ }^{91}$ Similar examples are easily found with regard to the financial aspect of innovation systems in Japan, Taiwan, and South Korea, among others. ${ }^{92}$ Therefore, extending these practices to foster policy making on innovation of other backward countries seems both plausible and admissible from a theoretical viewpoint.

\subsection{Leadership}

The argument that innovation carried out by the public sector itself plays a leading role in increasing business innovations is another essential feature of the NIS framework which, however an extended practice, is not endorsed by the received theory on technology and growth.

In the growth literature there is large, though not full, consensus that the government should undertake investments in research programs that, by their nature, are

\footnotetext{
${ }^{87}$ Cohen (2010), Mokyr (2010), Mazzucato (2013).

${ }^{88}$ Cohen (2010), Hall and Lerner (2010).

${ }^{89}$ Almus and Czarnitzki (2003), Dosi et al. (2006), Hall and Lerner (2010), Becker and Hall (2013).

${ }^{90}$ The limited role of the venture capital market is a feature even in advanced economies; see Mazzucato (2013), Stiglitz (2014).

${ }^{91}$ Mowery and Rosenberg (1993), Cohen (2010), Mazzucato (2013), Mazzucato and Semieniuk (2017), Breznitz et al. (2018).

${ }^{92}$ Kim (1993), Freeman (1995), and Wade (1996), Breznitz (2007).
} 
unattractive for the private sector as, for instance, long-run, high-cost and risky infrastructure projects, pure science or basic research in pioneering fields (nanotechnology, biotechnology, green-tech).

The crucial aspect highlighted from the perspective of the NIS framework is that the research conducted in public laboratories is not only a centerpiece in increasing basic science and technological knowledge, but in enhancing the conditions that lead to the introduction of new technologies and spur innovation in the business sector. However, for profit-making firms, basic research is not only a source of inspiration. Empirical investigation in this area has confirmed that business firms benefit not only from the knowledge but even by the commercialization of products resulting from public research in a variety of areas from agriculture to food production and renewable energy, and from basic electronics to the internet. ${ }^{93}$

Thus, unlike the mainstream emphasis that the key role of government is enabling the market "conditions" that spur innovation, the NIS perspective is that public research has large external effects on the private sector commercial innovation activity. Technology originated in the public sector and subsequently handed out to the private sector allows the latter to take over only the more profitable commercialization role without the cost of investment. Moreover, public research has been extensively argued to have large influence on the kind and direction of innovation activities conducted in the private sector, and have even been a widespread practice to "shape" and "create" new markets for innovations (clean-energy) when those markets are absent or poorly developed. ${ }^{94}$

Extended research in this line of investigation has called into question the prevailing view that technology and innovation are better encouraged in competitive markets where there is no government intervention. Researchers have pointed out that, on the contrary, government leadership in this regard has been a feature of most advanced countries. For example, in the case of the US economy, there are lots of examples of technology initiated by the government that later goes out to the business sector for commercialization. Earlier, the focus was on technologies linked to military purposes, but subsequent research conducted in federal State agencies (NSF, NASA, USDD, USDA, SBA), or directly sponsored by them (DARPA, ARPA-E, SBIR, IQT), and subsequently disseminated to the business sector is widely documented, ${ }^{95}$ as the following quote notes

...An extensively studied extraindustry influence on technological opportunity is that of government. In numerous sectors, notably agriculture, aircraft, electronics, and medicine, government has contributed to reducing the private cost of innovation and has influenced the direction of industrial research by its own research, by its support of academic research, by subsidizing and sponsoring private sector research and by disseminating technological knowledge

\footnotetext{
${ }^{93}$ Cohen (2010), Mokyr (2010), Mazzucato (2013).

${ }^{94}$ Moreau (2004), Trajtenberg (2002), Breznitz (2007), Foray and Lissoni (2010), Mazzucato (2013), Mazzucato and Semieniuk (2017), Breznitz et al. (2018).

${ }^{95}$ Mowery and Rosenberg (1993), Mazzucato (2013), Mazzucato and Semieniuk (2017), Breznitz et al. (2018).
} 
developed in its own labs and elsewhere. The distribution of government expenditures on $R \& D$ across industries is highly skewed, especially in the United States, where industries supplying the military, and, more recently, universities conducting research in the life sciences, are the principal recipients of $R \& D$ support. Although its direct role in creating and disseminating knowledge is substantial in some sectors, its indirect influence is also felt through a variety of other channels that have different impacts across industries. Most important is the impact of government demand on the rate and direction of innovation. ${ }^{96}$

Another example in regard to government leadership is the NIS project itself, which emerged from the concern in industrialized countries over finding alternatives aimed at enhancing competitiveness and growth prospects. The NIS initiative, in this context, is considered to be a way toward understanding the determinants and enhancing the creation and diffusion of knowledge throughout the economy. ${ }^{97}$ This concern has been central to the support of a permanent production of country-based studies and the standardization of performance indicators focused on patterns of knowledge and innovative potentials that allow comparisons across countries. ${ }^{98}$

\subsection{Coordination}

Coordination failures are largely featured in mainstream economics as market failures: situations where the economy exhibits low levels of activity because of a divergence between private and social optimal choices, and where the difference is sufficient to warrant some type of external (government) intervention, though the appropriate instruments to intervene and the extent, form and duration of such interventions are, in general, issues of debate.

In the NIS perspective, where innovation is regarded as the result of a collective process that encompasses a variety of actors, knowledge, institutions, and public-private interactions, the issue of coordination receives more extended attention. Public action is held necessary to ease the configuration of network connections, encourage collaboration and strengthen the complementarities and interdependencies between the different actors contributing to the whole process. ${ }^{99}$

In general terms, the problem of coordination failures is inevitable in a market economy. In order to correct the deficiencies that, in this regard, can undermine the potential for innovation, the research on the theoretical front has emphasized on either of three sets of policies: policies that influence the allocation of resources, policies that encourage sectoral complementarities, or a combination of both. Mainstream economics emphasizes mostly on the allocation mechanism. It sees the lack of "synergism" or "complementarity" between different economic activities as arising overall from "market rigidities" that can be remedied simply by influencing the

\footnotetext{
${ }^{96}$ Cohen (2010), pp. 179.

${ }^{97}$ See, Freeman $(1987,1995,2004)$.

${ }^{98}$ Mairesse and Mohnen (2010), Soete et al. (2010).

${ }^{99}$ Nelson and Winter (2002), Nelson (2008), Laperche et al. (2008).
} 
price mechanism. ${ }^{100}$ Consequently, from this perspective, the key strategy to boost innovation hinges on the ability of government to provide price incentives using conventional policy instruments (taxes, subsidies, interest rates, wages) - though, as it is usually remarked, that approach involves the risk of introducing further distortions.

The NIS framework focuses instead on the potentials of the complementarity approach. The rationale is similar, though not completely analogous, to the "bigpush" approach: investments in innovation in one sector may fail to occur whenever complementary investments are not made in other sectors. ${ }^{101}$ For instance, as pointed out by Ramalingam and Bound, a single invention, like the car, would have failed to revolutionize the transport system were it not be accompanied by a range of complementary developments in both product and service innovations: roads, traffic lights and regulation, petrol stations, driving schools, and so on. ${ }^{102}$

The interactive nature of innovation in this perspective-where innovation is conducted partly by firms in the business sector, and partly by non-market organizations (e.g., universities, government agencies) domestically and abroad-implies a more extensive role for government action which, as we have already pointed out earlier in this paper, typically involves aspects of networking and collaboration between the distinct parts of the system, and policies to encourage knowledge transfers from international sources. ${ }^{103}$ Certainly, these aspects are not disputed by the mainstream theory, but, as we have discussed in a previous section, the NIS literature goes much further in its analysis to stress the interaction across different parts of the innovation system through all kinds of market and non-market mechanisms. ${ }^{104}$

Regarding the duration aspect, the mainstream view is that any intervention to adjust coordination failures should be limited to the time necessary to get the economy out of the situation with low levels of activity. ${ }^{105}$ By contrast, government intervention is a permanent feature of the NIS approach beyond typical business cycles considerations. ${ }^{106}$ It relates to the common perspective between the NIS and evolutionary literatures that innovation, economic growth and catching up are everchanging phenomena, which means that they cannot be properly assessed as if they were states of equilibrium. ${ }^{107}$

Summing up, the view of government interventions emphasizing networking and collaboration over the logic of firms competition and self-organizing markets, is a crucial hallmark of the NIS approach. From this viewpoint, the issue of coordination

\footnotetext{
${ }^{100}$ Ball and Romer (1991), Mankiw and Romer (1997).

${ }^{101}$ Murphy et al. (1989), Soete et al. (2010).

${ }^{102}$ Ramalingam and Bound (2016).

${ }^{103}$ Moreau (2004).

${ }^{104}$ Nelson (1993), Nelson (2008), Foray and Lissoni (2010), Stephan (2010), Soete et al. (2010).

${ }^{105}$ As an example of this way of thinking, Murphy et al. (1989) hold that, in the face of coordination failures, government intervention may help to move the economy from any "inferior" toward a "superior" equilibrium. That is, consistent with the market-failure approach, they hold that the temporal intervention of the government must cease at the point where the market has reached a "superior" equilibrium. See also Ball and Romer (1991).

${ }^{106}$ Mazzucato and Semieniuk (2017).

${ }^{107}$ Nelson (2008).
} 
is more demanding and involves more complex interactions than temporal interventions for the sake of solving market failures. Therefore, under the innovation systems approach, public action is permanently needed to enact broad policy directions, establish/adjust the institutional framework, and generate networks, partnerships and collaboration to promote the creation and diffusion of innovation among different parts of the economic system. The degree to which countries are (un)able to thread the whole NIS is symptomatic in understanding their growth and catching up performance. ${ }^{108}$

\section{Concluding remarks}

The review in this paper has sought to contribute to the academic understanding of the economics of technology and innovation with a specific focus on the implications for policy-making and catching up issues in backward countries. In doing so, we started by looking at the conventional understanding and use of the notions of technology and innovation in growth economics and have called attention to widespread ideological issues and common ambiguities that, in our view, have prevented the profession from a clear understanding of why/how innovation, rather than technology diffusion, is the actual engine of growth and catching up. Next, we have stressed the importance of broadening the definition of innovation along the lines promulgated by novel contributions from the evolutionary theory.

Then, we have argued why the theoretical frameworks provided by the mainstream, evolutionary and NIS perspectives, put together, aim for a better understanding of the aspects of technology and innovation which appear important in explaining the prospects of backward countries to catching up. Such a combined approach, we have argued, would require a wider intellectual support for innovation-based growth models that stress thinking about the long-run, a broad view of innovation and active public action to encourage business innovations.

Finally, an issue that has been particularly important in our assessment relates to the conceptual and methodological differences between the conventional notion of advantage of backwardness and the NIS framework- the fundamental premises of which call for public actions to encourage business innovation and entrepreneurship through its impact on the three essential aspects of sponsorship, leadership and coordination of a country's innovation system. The most salient policy implications of our analysis in this regard highlight the need to focus on innovation rather thanthough by no means instead of - on more typical elements of absorptive capacities, technology acquisition/imitation and price competitiveness; and the need to focus on such issues as financial mechanisms, State entrepreneurship, experimentation and discovery, business networking, collaboration and public-private partnerships

\footnotetext{
${ }^{108}$ Though they are not in the scope of this section, we cannot ignore two important criticisms of government intervention: the first is the possibility of "government failures", as mainstream economics holds that intervention can do more harm than good to the economy; the second is political constraints, for example, barriers to technology adoption raised by special interests Parente and Prescott (2002).
} 
rather than-but, again, not instead of-on conventional aspects that stress firms competition and the logic of self-organizing markets.

While the discussion we have provided here has by no means been exhaustive, certainly we have shown that the main conclusions of our assessment are abundantly supported by very different strands of the literature on innovation. That makes, in our view, a strong case for revisiting both the foundations of growth theory, and the policy frameworks and incentive structures thought to promote growth and development, particularly when it comes to less developed countries.

Acknowledgments The author gratefully acknowledges the comments and suggestions received from Thomas Ziesemer at Maastricht University School of Business and Economics, and Bart Verspagen (UNUMERIT). The comments of three anonymous referees and from the editor of this journal are also greatly appreciated. The usual disclaimers apply

\section{Compliance with Ethical Standards}

Conflict of interests This investigation has been fully funded by the Maastricht University - School of Business and Economics. The author declares that there are no further conflicts of interest related with this work.

Open Access This article is distributed under the terms of the Creative Commons Attribution 4.0 International License (http://creativecommons.org/licenses/by/4.0/), which permits unrestricted use, distribution, and reproduction in any medium, provided you give appropriate credit to the original author(s) and the source, provide a link to the Creative Commons license, and indicate if changes were made.

Publisher's note Springer Nature remains neutral with regard to jurisdictional claims in published maps and institutional affiliations.

\section{References}

Acemoglu D (2014) Localized and biased technologies: Atkinson and Stiglitz's new view, induced innovations, and directed technological change. National Bureau of Economic Research working paper No. w20060

Acemoglu D, Robinson J (2000) Political losers as a barrier to development. Am Econ Rev. May

Acemoglu D, Zilibotti F, Aghion P (2006) Distance to frontier, selection and economic growth. J Eur Econ Assoc 4(1):37-74

Aghion P, Akcigit U, Howitt P (2013) What do we learn from Schumpeterian growth theory? National Bureau Of Economic Research working paper no. w18824

Aghion P, Howitt P (2006) Joseph Schumpeter lecture appropriate growth policy: a unifying framework. J Eur Econ Assoc 4(2-3):269-314

Almus M, Czarnitzki D (2003) The effects of public R\&D subsidies on firms' innovation activities: the case of East Germany. J Bus Econ Stat 21(2):226-236

Anderson P, Arrow K, Pines D (1988) The economy as an evolving complex system I

Ang J, Madsen J (2011) Can second-generation endogenous growth models explain the productivity trends and knowledge production in the Asian miracle economies? Rev Econ Stat 93(4):1360-1373

Arthur W (1994) Increasing returns and path dependence in the economy, Ann Arbor. University of Michigan Press, Ann Arbor

Arthur W, Durlauf S, Lane D (1997) The economy as an evolving complex system II

Baldwin R (1971) Determinants of the commodity structure of U.S. trade. Am Econ Rev 61(1):126-146

Ball L, Romer D (1991) Sticky prices as coordination failure. Am Econ Rev:539-552

Barro R (1997) Determinants of economic growth. MIT Press, Cambridge 
Barro R, Sala-i-Martin X (1997) Technological diffusion and convergence. Journal of Economic Growth, March

Baumol W (2002) The free-market innovation machine: analyzing the growth miracle of capitalism. Princeton University Press, Princenton

Becker B, Hall S (2013) Do R\&D strategies in high-tech sectors differ from those in low-tech sectors? An alternative approach to testing the pooling assumption. Econ Chang Restruct 46(2):183-202

Benhabib J, Perli R (1994) Uniqueness and indeterminacy: on the dynamics of endogenous growth. J Econ Theory 63(1):113-142

Benhabib J, Spiegel MM (2005) Human capital and technology diffusion. Handbook of Economic Growth 1:935-966

Benhabib J, Perla J, Tonetti C (2014) Catch up and fall-back through innovation and imitation. J Econ Growth 19(1):1-35

Bernard A, Jones C (1996) Comparing apples to oranges: productivity convergence and measurement across industries and countries. Am Econ Rev:1216-1238

Blume L, Durlauf S (eds) (2005) The economy as an evolving complex system, III: current perspectives and future directions. Oxford University Press, London

Boldrin M, Levine D (2002) The case against intellectual property. Am Econ Rev 92(2):209-212

Breznitz D (2007) Innovation and the state: political choice and strategies for growth in Israel, Taiwan, and Ireland. Yale University Press, New Haven

Breznitz D, Ornston D, Samford S (2018) Mission critical: the ends, means, and design of innovation agencies. Ind Corp Chang 27(5):883-896

Bullard J, Butler A (1993) Nonlinearity and chaos in economic models: implications for policy decisions. Econ J:849-867

Castellion G, Markham S (2013) Perspective: new product failure rates: influence of argumentum ad populum and selfinterest. J Prod Innov Manag 30(5):976-979

Cimoli M, Hofman A (2010) Innovation and economic development: the impact of information and communication technologies in Latin America. Edward Elgar Publishing, Cheltenham

Coe D, Helpman E (1995) International R\&D spillovers. Eur Econ Rev 39(5):859-87

Cohen W (2010) Fifty years of empirical studies of innovative activity and performance. Handbook of the Economics of Innovation 1:129-198

Cohen W, Levinthal D (1989) Innovation and learning: the two faces of R\&D. Econ J 99(397):569-596

De Long J, Summers L (1991) Equipment investment and economic growth. Q J Econ 106(2):445-502

Dinopoulos E, Syropoulos C (2007) Rent protection as a barrier to innovation and growth. Econ Theory 32(2):309-332

Dosi G (2013) The third industrial revolution in global business. Cambridge University Press, Cambridge

Dosi G, Nelson R (2010) Technical change and industrial dynamics as evolutionary processes. Handbook of the Economics of Innovation 1:52-114

Dosi G, Marengo L, Pasquali C (2006) How much should society fuel the greed of innovators? on the relations between appropriability, opportunities and rates of innovation. Res Policy 35(8):1110-1121

Dreher A (2009) IMF conditionality: theory and evidence, theory and evidence. Public choice 141:233267

Easterly W, Levine R (2001) What have we learned from a decade of empirical research on growth? It's not factor accumulation: stylized facts and growth models. World Bank Econ Rev 15(2):177-219

Fagerberg J (1994) Technology and international differences in growth rates. J Econ Lit

Fagerberg J, Verspagen B (2002) Technology-gaps, innovation-diffusion and transformation: an evolutionary interpretation. Res Policy 31:1291-1304

Fagerberg J, Srholec M, Verspagen B (2010) Innovation and economic development. Handbook of the Economics of Innovation 2:833-872

Foray D, Lissoni F (2010) University research and public-private interaction. Handbook of the Economics of Innovation 1:276-308

Freeman C (1987) Technology policy and economic performance: lessons from Japan. Pinter Publishers, London, pp 11-17

Freeman C (1994) The economics of technical change. Camb J Econ 18(5):463-514

Freeman C (1995) The "National System of Innovation" in historical perspective. Camb J Econ 19(1):5-24

Freeman C (2004) Technological infrastructure and international competitiveness. Ind Corp Chang 13(3)

Gault F (2014) Where are innovation indicators, and their applications, going? UNU-MERIT working paper series 2014-055 
Gordon R (2014) The demise of U.S. economic growth: restatement, rebuttal, and reflections. National Bureau of Economic Research working paper no. 19895

Grossman G, Helpman E (2001) Innovation and growth in the global economy, 7th edn. MIT Press, Cambridge

Ha J, Howitt P (2007) Accounting for trends in productivity and R\&D: a Schumpeterian critique of semiendogenous growth theory. J Money Credit Bank 39(4):733-774

Hall B, Lerner K (2010) The financing of R\&D and innovation. Handbook of the Economics of Innovation 1:610-635

Hall B, Rosenberg N (eds) (2010) Handbook of the economics of innovation, vol 1. Elsevier

Hall P, Soskice D (2003) Varieties of capitalism: the institutional foundation of comparative advantage. Oxford University Press, Oxford

Hall R, Jones C (1999) Why do some countries produce so much more output than others? Q J Econ 114:83-116

Hausmann R, Hidalgo C, Bustos S, Coscia M, Chung S, Jimenez J, Simoes A, Yildirim M (2011) The atlas of economic complexity. Boston, MA

Herstatt C, von Hippel E (1992) From experience: developing new product concepts via the lead user method: a case study in a "low-tech" field. J Prod Innov Manag 9(3):213-222

Hirsch-Kreinsen H (2008) "Low-tech" innovations. Ind Innov 15(1):19-43

Hobday M (1995) East Asian latecomer firms: learning the technology of electronics. World Dev 23(7):1171-1193

Huang C, Arundel A, Hollanders H (2010) How firms innovate: R\&D, non-R\&D, and technology adoption. UNU-MERIT WP. 2010-027

Jones C (1995) Times series tests of endogenous growth models. Q J Econ 110:495-525

Jones C (2005) Growth and ideas. Handbook of Economic Growth 1:1063-1111

Jorgenson D, Vu K (2010) Latin America and the world economy. In: Cimoli et al (eds) Innovation and economic development: the impact of information and communication technologies in Latin America. Edward Elgar Publishing, pp 19-42

Jorgenson D, Gollop F, Fraumeni B (1987) Productivity and US economic growth

Kasahara S (2004) The flying geese paradigm: a critical study of its application to East Asian regional development

Keller W (2004) International technology diffusion. J Econ Lit 17(Sep):752-782

Kim L (1993) National systems of industrial innovation: dynamics of capability building in Korea. In: Nelson R (ed) National innovation systems: a comparative analysis, pp 357-383

Kremer M (1998) Patent buyouts: a mechanism for encouraging innovation. Q J Econ, November

Kumar S, Russell R (2002) Technological change, technological catch up, and capital deepening: relative contributions to growth and convergence. Am Econ Rev:527-548

Lall S (2000) The technological structure and performance of developing country manufactured exports, 1985-98. Oxf Dev Stud 28(3):337-369

Laperche B, Munier F, Hamdouch A (2008) The collective innovation process and the need for dynamic coordination: general presentation. Journal of Innovation Economics \& Management, (2):3-13

Lee K (2013) Schumpeterian analysis of economic catch up: knowledge path-creation, and the middle income trap. Cambridge

Le Grand J (1991) The theory of government failure. Br J Polit Sci 21(4):423-442

Lerner J, Stern S (2019) Innovation policy and the economy: introduction to volume 19. Innovation Policy and the Economy 19(1):xi-xiv

Lin J, Monga C, te Velde D, Tendulkar S, Amsden A, Amoako K, Lim W (2011) DPR debate: growth identification and facilitation: the role of the state in the dynamics of structural change. Dev Policy Rev 29(3):259-310

Lucas R (1988) On the mechanics of economic development. J Monet Econ 22:3-42

Lucas R (2000) Some macroeconomics for the 21st century. J Econ Perspect: 159-168

Lucas R (2009) Trade and the diffusion of the industrial revolution. Am Econ J Macroecon 1(1):1-25

Lundvall B (2007) National innovation systems - analytical concept and development tool. Ind Innov 14(1):95-119

Madsen J, Islam M, Ang J (2010) Catching up to the technology frontier: the dichotomy between innovation and imitation. Can J Econ 43(4):1389-1411

Mairesse J, Mohnen P (2010) Using innovation surveys for econometric analysis. Handbook of the Economics of Innovation 2:1129-1155 
Mankiw G, Romer P (eds) (1997) New Keynesian economics: coordination failures and real rigidities, vol 2. MIT Press, Cambridge

Mankiw G, Phelps E, Romer P (1995) The growth of nations. Brook Pap Econ Act: 275-326

Mazzucato M (2013) The entrepreneurial state: debunking public vs. private sector myths, vol 1. Anthem Press, London

Mazzucato M, Semieniuk G (2017) Public financing of innovation: new questions. Oxf Rev Econ Policy 33(1):24-48

McMillan M, Rodrik D (2012) Globalization, structural change, and productivity growth. International food policy research institute, working paper 01160

Medio A, Negroni G (1996) Chaotic dynamics in overlapping generations models with production. In: Barnett W, Kirman A, Salmon M (eds) Non linear dynamics and economics. Cambridge University Press

Mokyr J (2010) The contribution of economic history to the study of innovation and technical change: 1750-1914. In: Handbook of the economics of innovation, vol 1, pp 11-47

Mokyr J (2014) Secular stagnation? Not in your life. secular stagnation: facts. Causes and cures, 83

Moreau F (2004) The role of the state in evolutionary economics. Camb J Econ 28(6):847-874

Mowery D, Rosenberg N (1993) The U.S. national innovation system. In: Nelson R (ed) National innovation systems: a comparative analysis, pp 29-75

Murphy K, Shleifer A, Vishny R (1989) Income distribution, market size, and industrialization. Q J Econ 104(3):537-564

Nelson R (1993) National innovation systems: a comparative analysis. University of Illinois at UrbanaChampaign's Academy for entrepreneurial leadership historical research reference in entrepreneurship

Nelson R (2008) Economic development from the perspective of evolutionary economic theory. Oxf Dev Stud 36(1):9-21

Nelson R, Winter S (1982) An evolutionary theory of economic change. Belknap, Cambridge

Nelson R, Winter S (2002) Evolutionary theorizing in economics. J Econ Perspect 16(2):23-46

Nishioka S (2013) R\&D, trade in intermediate inputs, and the comparative advantage of advanced countries. Journal of the Japanese and International Economies 30:96-110

OECD (2005) The oslo manual: the measurement of scientific and technological activities guidelines for collecting and interpreting innovation data, 3rd edn. OECD/Eurostat, Paris

Pack H, Nelson R (1999) The Asian miracle and modern growth theory. The world bank

Parente S, Prescott E (2002) Barriers to riches, vol 3. MIT Press, Cambridge

Phelps E (2016) What is wrong with the west's economies? Homo Oeconomicus 33(1-2):3-10

Pritchett L (1997) Divergence big time. J Econ Perspect, Summer

Ramalingam B, Bound K (2016) Innovation for international development. Navigating the paths and pitfalls

RICYT (2005) El estado de la ciencia. Principales indicadores de ciencia y tecnología iberoamericanosinteramericanos. RICYT/OAS/CYTED, Buenos Aires

Romer P (1986) Increasing returns and long-run growth. J Polit Econ 94(5):1002-37

Romer P (1993) Idea gaps and object gaps in economic development. J Monet Econ 32(3):543-573

Romer P (1994) The origins of endogenous growth. J Econ Perspect: 3-22

Romer P (2000) Should the government subsidize supply or demand in the market for scientists and engineers? NBER working papers 7723, National Bureau of Economic Research, Inc.

Sachs J, McArthur W (2002) Technological advancement and long-run economic growth in Asia. In: Bai C, Yuen C (eds) Technology and the new economy, Ch. 4. MIT Press, Cambridge, pp 157-85

Safarzyńska K., van den Bergh J (2010) Evolutionary models in economics: a survey of methods and building blocks. J Evol Econ 20(3):329-373

Schmookler J (1966a) Invention and economic growth, vol 26. Harvard University Press, Cambridge

Schneider J, Ziesemer T (1995) What's new and what's old in new growth theory: endogenous technology, microfoundation and growth rate predictions. Zeitschrift fur Wirtschafts-u Sozialwissenschaften (ZWS) 115:429-472

Schumpeter J (1934) The theory of economic development. Harvard University Press, Cambridge

Schumpeter J (1950) Capitalism, socialism, and democracy, 3rd edn., New York

Scott A (2006) The changing global geography of low-technology, labor-intensive industry: clothing, footwear, and furniture. World Dev 34(9):1517-1536

Silverberg G (1997) Evolutionary modelling in economics: recent history and immediate prospects. MERIT 
Silverberg G, Lehnert D (1996) Evolutionary chaos: growth fluctuations in a Schumpeterian model of creative destruction. In: Barnett W, Kirman A, Salmon M (eds) Non linear dynamics and economics. Cambridge University Press

Silverberg G, Verspagen B (1995) Evolutionary theorizing on economic growth. In: Dopfer K (ed) The evolutionary principles of economics. IIASA, MERIT, Cambridge. WP-95-76 and 2/95-017

Simon H (1979) Rational decision making in business organizations [Nobel Memorial Lecture]. Am Econ Rev 69(4):493-513

Schmookler J (1966b) Invention and economic growth

Smith A (1776) An inquiry into the nature and causes of the wealth of nations: volume One. London: printed for W. Strahan and T. Cadell, 1776

Snowdon B, Vane H (2005) Modern macroeconomics: its origins, development and current state. Edward Elgar Publishing, Cheltenham

Soete L, Verspagen B, ter Weel B (2010) Systems of innovation. Handbook of the Economics of Innovation 2:1159-1180

Som O, Kirner E (2016) Low-tech innovation. Springer, New York

Spence M (2011) The next convergence: the future of economic growth in a multispeed world. Macmillan, London

Stephan P (2010) The economics of science. In: Handbook of the Economics of Innovation, vol 1, pp 218273

Stiglitz J (2008) Government failure vs. market failure: principles of regulation

Stiglitz J (2014) Leaders and followers: perspectives on the nordic model and the economics of innovation. $\mathrm{J}$ Public Econ, Leaders and followers

Stiglitz J, Heertje A (eds) (1989) The economic role of the state. Wiley-Blackwell, Hoboken

Stokey N (2012) Catching up and falling behind. J Econ Growth 20(1):1-36

Thaler R (2015) Misbehaving: the making of behavioral economics. New York, W. W. Norton \& Company

Trajtenberg M (2002) Government support for commercial R\&D: Lessons from the Israeli experience. In: Jaffe A., Lerner J., Stern S (eds) Innovation policy and the economy, vol 2, Cambridge, pp 79-134

Verspagen B (1993) Uneven growth between interdependent economies: evolutionary view on technologygaps trade and growth. Avebury, Aldershot

Wade R (1996) Japan, the world bank, and the art of paradigm maintenance: "The East Asian Miracle" in political perspective. New Left Review(217), 3

Wirkierman A, Ciarli T, Savona M (2018) Varieties of european national innovation systems

Ziesemer T (1991) Human capital, market structure and taxation in a growth model with endogenous technical progress. J Macroecon 13(1):47-68

Ziesemer T (1995) Endogenous growth with public factors and heterogeneous human capital producers. Finanz Archiv 52(1):1-20

Zilibotti F (2008) Economic growth through the development process. CESifo Econ Stud 54(3):325-357 